\title{
Impact of Microcredit on Rural Poverty Alleviation in the Context of Bangladesh
}

\author{
Shakina Sultana Pomi ${ }^{1}$ \\ ${ }^{1}$ Faculty of Business Administration, Southern University Bangladesh, Chittagong, Bangladesh \\ Correspondence: Shakina Sultana Pomi, Assistant Professor, Faculty of Business Administration, Southern \\ University Bangladesh, 739/A, Mehdibag Road, Chittagong-4000; Bangladesh. E-mail: \\ shakina_sultana@yahoo.com
}

Received: March 29, 2019

Accepted: April 24, 2019

Online Published: May 5, 2019

doi:10.5539/ijef.v11n6p70

URL: https://doi.org/10.5539/ijef.v11n6p70

\begin{abstract}
Microcredit and poverty alleviation have become the two sides of a coin as the role of microcredit on poverty alleviation is well accepted in the arena of economic development. This study is an attempt to analyse the impact of microcredit on poverty alleviation in the rural areas namely Hathazari, Mirsharai and Sitakunda upazilla (sub-units of district ) of Chittagong district, Bangladesh. A cross sectional survey was conducted on the rural part of these three upazillas. Data have been collected through a well-structured questionnaire from 100 microcredit-recipients/borrowers of Bangladesh Rural Advancement Committee (BRAC) and Association for Social Advancement (ASA) - two giant microcredit providers in Bangladesh and from 50 non-borrowers of the study areas. Respondents were selected randomly. Tabular method was used to describe the data. Hypothetically, the outcomes were found significant resulted from chi-square test ( $\mathrm{X}^{2}$-test) and ANOVA (Analysis of Variance) without an exception for clothing expenditure. The study revealed that microcredit disbursed through BRAC and ASA, plays a dynamic role to reduce poverty in the study areas by income generating activities of the poor women borrowers and by improving their living standard. It is found from the study that microcredit has positive impact on income, expenditure, condition of dwelling house, education, health and decision making ability of the poor women borrowers who spent at least five years in BRAC and ASA comparing to the non-borrowers.
\end{abstract}

Keywords: microcredit, poverty alleviation, women borrowers

\section{Introduction}

Microcredit, interchangeably microfinance plays a paramount role in the socio-economic development of Bangladesh and in other developing countries since the last couple of decades by reducing poverty for the poors especially for the women. Microcredit is recognized as the most effective tool to fight against the poverty. Bangladesh is a developing country and poverty is one of the biggest problems; but over the last 35 years, Bangladesh has been successful in eradicating poverty at a remarkable rate and its success stories bring Bangladesh at global focal point.

Bangladesh is one of the density populated countries in the world. It has 160 million people in its domestic territory. The Human Development Index (HDI) ranked Bangladesh at 138 among 189 countries in 2016 (United Nations Development Program [UNDP], 2018). Data has been revealed that 49.6 percent population live below income at US\$1.25 (UNDP, 2012). Though most of the populations live below poverty line, they need to get support to do away with their poverty. In Bangladesh, a lot of Microfinance Institutions (MFI's) are working in this sector with a variety of products and programmes. Among these MFIs Grameen Bank (GB), Bangladesh Rural Advancement Committee (BRAC) and Association for Social Advancement (ASA) are the larger organizations which work for the poor community of the country. Numerous literatures and documentations in the sector of microcredit and poverty has been demonstrated the truth of positive impact of microcredit on the livelihood of poor women by alleviating poverty. To justify the impact of microfinance on the poor community this study has been done simply on the credit recipients of two MFI's namely BRAC and ASA. BRAC and ASA are playing worth mentioning role to reduce the vulnerabilities of the poor women in the rural areas of Bangladesh. Now, BRAC and ASA have been providing microfinance and related services to 5.3 million and 5.8 million poor household respectively all over the country (Bangladesh Rural Advancement Committee [BRAC], 2015 \& Association for Social Advancement [ASA], 2015). Due to enormous penetration of BRAC and ASA into the large community of rural areas, this study 
choose these two organizations to analyze the impact of microfinance on the livelihood of poor women of Hathazari, Mirsharai and Sitakunda area of Chittagong district of Bangladesh.

In the field of socio-economic development, the word 'microfinance' and 'poverty' got immense popularity as a research topic in the context of Bangladesh. Poverty reduction is the one of the major goal of Millinium Development Goals (MDGs). Microfinance has contributed at least 9-12 percent to the GDP of Bangladesh (Raihan, Osmani, \& Khalily, 2015). Over the last 35 years, Bangladesh steadily but gradually improved its economic condition. In recent years, microfinance has been expanded both horizontally and vertically. Success stories of Bangladesh in the field of microfinance draw the attention of thousands of researcher, academics, research fellow, and Non-Govt. Organizations (NGOs) activists for its poverty alleviation role. This study is also an attempt to share the findings in the basket of its success stories.

\subsection{Relevant Scholarly Works in the Field of Microcredit}

Vast empirical literatures have been studied to evaluate the nature and effects of microcredit on livelihood of poor women borrowers. Despite, the role of microcredit in poverty reduction is infrequently conflicting between positive, no impact and even negative, till today, microcredit is recognized as the most effective tool to fight against the poverty. Numerous studies on the impact of microcredit revealed the positive impact of microcredit on poverty alleviation and in improvement of livelihood of poor women.

Terano, Mohamed, and Jusri (2015) conducted a survey on 100 credit recipients and illustrated the impact of microcredit on total income level by using descriptive analysis, factor analysis and multiple regression analysis. Islam, Hossain and Afrin (2014) examined the impact of microcredit on poverty reduction from 100 microcredit recipients of Grameen Bank, BRAC and ASA using structured questionnaire and found that these MFIs play important role to reduce poverty by generating employment and improving living standard by better education, health facilities and higher health expenditure. In another study, Khanam (2014) found a slight improvement in income level of the Rural Microcredit (RMC) household. Khan and Karim (2016) described that one third of the borrowers were able to increase their household income found from the survey conducted on BRAC and Grameen Bank which also revealed that 5.5 percent borrower of Grameen Bank and 2.99 percent borrowers of BRAC were able to raise poverty level and about 68 percent borrowers of Grameen Bank were found to cross the poverty line. Khandker, Khalily and Samad (2015) documented interesting results on the longer term effects of microcredit on household welfare, utilizing a panel data of households covering 87 villages of rural Bangladesh and they estimated long run effects of microcredit on household per capita income, expenditures, poverty, non-land assets, household net-worth, male \& female labor supply and schooling of children. In another study, Khandker (1998) observed that microcredit has positive impact on reducing poverty, but the rate of extreme poverty reduction is higher than moderate poverty.

Kondo, Aniceto, Dingcong, and Infantado (2008) carried out an impact evaluation study on the Rural Microenterprise Finance Project (RMFP) in the Philippines using the difference-in-difference estimation technique and outcomes of the study showed a mildly significant positive impact on per capita income, per capita total expenditure and per capita food expenditure. Finally, the result leaded the authors to recommend that microfinance programs to be effective as a poverty-alleviation tool for RMEP (Kondo et al., 2008). In another study Kondo (2007) found no significant impact on household assets as well as on human capital investments, such as health and education and mild impact on income and expenditures.

Neponen (2003) collected data by a unique technique namely Internal Learning System (ILS) which was developed by ASA, to keep track of the changes in clients own living situations and where members crosschecked each other's reports for accuracy. In the ILS study, Neponen (2003) found better outcomes for long term members i.e. sixty-four percent lived in tile roof and concrete houses, compared to only 50 percent of newer members; eighty percent of their sons and their daughters of long term members attended school compared to 74 percent of sons and 65 percent of daughters of newer members. Sengsourivong (2005) investigated the impact of Savings Groups (SGs) programs on household income, expenditure and asset and revealed that SGs boosted programmes brought certain changes; SGs boosted educational expenditures implying activation of human capital formation, increased the house asset suggesting villagers investment reflected by possible business activation and brought a possible shift in income sources from traditional agriculture to livestock raising. Coleman (1999) conducted a survey on the "control" members and "treatment" members by using data from a quasi-experiment in Northeast Thailand in 1995-1996 and demonstrated that microfinance positively affect many measures of household welfare for the wealthy committee members, but the impact was found largely insignificant for poorer ranked file members.

A survey conducted by Hossain (2012) using semi-structured questionnaire from 208 peoples who borrowed from 
BRAC microfinance revealed that BRAC-microfinance operation has a positive impact on occupation, expenditure, savings, employment generation, dwelling house of the responded borrowers. Hossain (2012) used both qualitative and quantitative data on 'before' and 'after' of microcredit receipt to find overall impact of microfinance that was found positive. Rahman, Junankar, and Mallik (2009) examined the impact of microcredit on women's empowerment of borrowers having different levels of income, which showed that non-borrowers were equally empowered as microcredit borrowers by using control-group. Chowdhury, Ghosh, and Wright (2005) conducted a study on 954 samples, collected from Grameen Bank, BRAC and ASA and disclosed two findings -firstly, microcredit was associated with both lower subjective and objective poverty and lastly, the impact of microcredit on poverty was particularly strong for those that were involved for about six year. Karim, Tania, and Frarazi (2012) found in their study that microcredit programmes have generated positive results for large number of poor people. Islam, Kabir, and Dey (2012) conducted a study on ASA and PROSHIKA that interpreted the contribution of microcredit on poverty eradication by increasing the income generation activities, empowerment of poor peoples to access development services such as health, education and reduction in vulnerability. Khan and Rahman (2007) also discussed in their study that microfinance is one of the most important and effective mechanisms for poverty alleviation.

Mago (2014) observed that financial services such as savings, credit, insurance and money transfer payment have a significant impact on income, consumption, employment, social status and empowerment. Samer, Majid, Rizal, Halim, and Rashid (2015) examined the role of Malaysian Microfinance Institution by using its credit product 'AmanahIkhtial Malaysia (AIM)' on the income level of the beneficiaries and analyzed the impact of the AIM on household income. Awan and Juiya (2015), Idris (2015), Alnaa and Ahiakpor (2015) also found positive impact of microcredit on poverty reduction.

Recently, some studies argued on the impact of microcredit with a question that the impact of microcredit is conflicting between positive, no impact and limited impact to the less poor and even negligible or negative impact on the poorest. Banerjee, Duflo, Glennerster, and Kinnan (2015) surveyed on 52 respondents to determine the impact of microfinance and used two goods to describe the impact of microcredit on consumption expenditure. Banerjee et al. (2015) found that expenditure of "durable goods" increased but expenditure of "temptation goods" declined and no significant difference was reported on health, education or women's empowerment. Although having some disagreement, the vast literature works revealed enough empirical and quasi-empirical evidences that supported the positive impact of microcredit in poverty alleviation. So without any question, it can be alleged that a well-designed microfinance or microcredit programme can thus substantially change the lives of the poor at the individual, household, enterprise and community levels and help raise the poor's out of poverty.

\subsection{Objectives of the Present Study}

Present study was conducted on poverty alleviation role of BRAC and ASA- the leading NGOs in this sector. Many studies have been conducted on the poverty alleviation role of microfinance in several distinct areas, but study on the said areas was few. Most of the researches are found to focus on the variables on an aggregate basis, like monthly income, monthly expenditure etc. But studies on the expenditure variables separated into nutrition expenditure, education expenditure, health expenditure, clothing expenditure were not instigated in remarkable quantities. The impact of microfinance on these variables was demonstrated separately in the present study, because all the above variables were considered to estimate the actual improvement of the livelihood of the poor community in the study areas. To examine, whether microcredit has positive or negative effects on income, expenditure, housing condition, area of land, assets, education, health and nutrition, pure drinking water and sanitation, this paper used one way Analysis of Variance (ANOVA) and Chi-square test to analyze the association and extent of contribution within the variables. Major objectives of the present study are:

- To evaluate the impact of microcredit on poverty alleviation in Chittagong of Bangladesh.

- To provide policy recommendation based on the findings.

\section{Methodology of the Study}

This study was basically explorative in nature. The study has adopted 'purposive sampling in selecting the samples, and used both unstructured and structured instruments for collection of data. Both statistical and econometric techniques were used for analyzing data and some relevant parametric tests were conducted for testing hypothesis.

\subsection{Sampling Design of the Study}

In this study, two samples have been considered. One sample has been selected from loan recipients (women borrowers) and the other from non-recipients of loan (non-borrowers).For simplicity, the study considered two 
MFI's namely BRAC and ASA for collecting data. Data was collected from the respondents using a face-to-face interview schedule (Questionnaire). Questionnaire comprised of information related to the background of respondents such as gender, age, education, number of family members and living standards and both quantitative and qualitative data about income, expenditure, saving and variables concerning living standard. Some structured questions and some dichotomous questions were asked to collect the information from the respondents. Our structured questionnaire was used to collect data for different outcome variables indicating 'before' and 'after' of receiving credit by the borrowers and 'before 5 years back' and 'current year' for the non-borrowers respectively. Dichotomous questions had only two response alternatives - yes or no.

\subsection{Selection of the Study Areas and Period of Data Collection}

Only three upazillas (sub-units of district) in Chittagong district (namely Hathazari, Sitakunda and Mirsharai) have been selected for the purposes of this study. Again, out of a total number of 25 branches, 10 branches of BRAC \& ASA ( 5 branches from BRAC and 5 from ASA) were selected to determine the credit recipients sample from the study areas. It was presumed that the study areas would represent the whole scenario of rural part of Bangladesh. The selection of the study areas was based on the following criteria- (a) covered by microcredit operation of BRAC and ASA and continuing poverty reduction programme since last 20 years, (b) number of unprivileged poor women was high and (c) geographically and environmentally the study areas were convenient for collection of data. The survey was conducted from January 15, 2015 to February 10, 2016.

\subsection{Selection of the Sample of Women Borrowers}

There were 15 branches of BRAC and 10 branches of ASA, operating in the study areas. Out of these 25 branches only 10 ( 5 branches of BRAC and 5 branches of ASA) have been selected for the study. From each branch, one village centers and 10 groups (each groups contains at least 10 persons) have been selected for investigation. All of the above selections have been done randomly. This study has selected 205 borrowers randomly at 5 percent level of significance on the basis of standardized random sampling formula. This study has primarily attempted to conduct interview of 205 borrowers and finally the study was successful in conducting interview of 100 borrowers. So the success rate is 48.78 percent.

\subsection{Selections of the Sample of Non-Borrowers}

Besides 100 borrowers, another set of 50 non borrower respondents were also selected as the control group who did not take any credit from BRAC or ASA or any other MFI to compare the consequences of the study. 50 non borrower respondents were also selected randomly.

\subsection{Types and Sources of Data}

The Current study was based on the extensive use of primary data. Primary data were collected from the household of three upazillas ( sub-units of district) of Chittagong district namely Hathazari, Mirsharai and Sitakunda for the purpose of the study. The primary data have been collected through structured questionnaire from the 150 respondents that included both borrowers (100 respondents) of BRAC \& ASA and non-borrowers (50 respondents). Personal interview method was used to collect the data. Moreover various books, journals, website and other publications of BRAC and ASA were used for reviewing the fact thoroughly.

\subsection{Operational Variables}

Operational variables considered in the study were monthly income, homestead gain, household assets, monthly expenditures, food expenditure, education expenditure, health expenditure, access to pure drinking water and sanitation. The operational variables used in the study have fully reflected the relative poverty levels of both groups of households.

\subsection{Analysis of Data}

Data of the respondents were analyzed by Mean Value Analysis and Statistical Analysis. Average value of the variables have been determined to evaluate two situations on 'before' and 'after' of the microcredit receipt by the borrowers and ' 5 years back' and 'current year' to recognize the living standard of non-borrowers from the study areas.

To examine the impact of microcredit on income, expenditure, housing condition, area of land, assets, education, health and nutrition, access to pure drinking water and sanitation, one way Analysis of Variance (ANOVA) was applied. It tested the null hypothesis as $\mathrm{H}_{0}: \mu_{1}=\mu_{2}=\mu_{3}=\ldots=\mu_{\mathrm{k}}$, degrees of freedom $\mathrm{v}=\mathrm{k}-1$ (Where $\mathrm{k}=$ number of samples). ANOVA was applied to calculate the variance between and within the samples by using ' $F$ ' ratio and Chi-square test was used to analyze the association and extent of contribution within the variables. 


\subsection{Limitations of the Study}

Like other research endeavor, present study was also cramped to some limitations e.g.; unavailability and inadequacy of data, illiteracy of the respondents, time \& cost constraint, biasness to MFI by the borrower etc. In this study, three (03) upazillas of Chittagong district were covered which could not represent the complete picture of the country. Being illiterate some borrowers and non-borrowers respondents were not able enough to distinguish the variable of the study and sometimes made complexity to draw the actual scenario regarding their livings and the impact of microcredit on their livelihood.

\section{Economic Analysis: Impact of Microcredit on Poverty Alleviation}

Obviously, successful utilization of borrowed money is expected to make a positive impact on the income of a borrower. The analysis of data affirmed to this fact. As described in table 1, it is found from the survey that average monthly income of the borrowers before taking credit was BDT 13500 and after using credit, it increased to BDT 22132 and average monthly income of the non-borrowers on '5 years back' was BDT 10000 and 'currently' it stood BDT 14912. From table 1, it is found that average monthly expenditure of borrowers before credit was BDT 9100 and after using credit, it increased to BDT 19,396 and average monthly expenditure of the non-borrowers on '5 years back' was BDT 12000 and 'currently' it stood BDT 12050. Table 1, also revealed the changes of other variables explicitly homestead, agricultural land, monthly expenditure, food expenditure, education expenditure, health expenditure, clothing and health \& nutrition on 'before credit' and 'after credit' for borrowers \& ' 5 years back' and 'currently' for non-borrowers. The average homestead areas of borrowers were 16.90 decimals and 24.39 decimals before and after using loans respectively. After 5 years the result has been changed for non-borrowers also, but not significantly.

Table 1. Average value of the variables of the borrowers and Non-borrowers

\begin{tabular}{lllll}
\hline Variables & \multicolumn{2}{l}{ Average of the borrowers } & \multicolumn{2}{l}{ Average of the Non-borrowers } \\
\cline { 2 - 5 } & Before credit & After credit & 5 years back & Currently \\
\hline Monthly income & BDT13500 & BDT 22132 & BDT 10000 & BDT 14912 \\
Homestead & 16.90 decimal & 24.39 decimal & 16.30 decimal & 7.08 decimal \\
Agricultural land & 19.50 decimal & 25.62 decimal & 19.10 decimal & 8.38 decimal \\
Monthly expenditure & BDT9100 & BDT 19396 & BDT 12000 & BDT 12050 \\
Food expenditure & BDT 6950 & BDT 11197 & BDT 9300 & BDT 8184 \\
Education expenditure & BDT 900 & BDT 1818 & BDT 1,050 & BDT 964 \\
Health expenditure & BDT 1200 & BDT 2736 & BDT 1,800 & BDT 1804 \\
Clothing expenditure & BDT 750 & BDT 1714 & BDT 900 & BDT 1512 \\
Health and nutrition expenditure & BDT 1420 & BDT 2505 & BDT 1700 & BDT 1574 \\
\hline
\end{tabular}

Table 2 portrayed the comparison of family's monthly income 'before' and 'after' of consuming credits by the borrowers and income earned 'five years back' and 'current' income by the non-borrowers.

Table 2. Comparison of different income and related variables before and after of consuming credits by the borrowers and current and five years back by the non-borrowers

\begin{tabular}{|c|c|c|c|c|c|}
\hline \multirow[b]{2}{*}{ Variables } & \multirow[b]{2}{*}{ Particulars(Ranges) } & \multicolumn{2}{|c|}{ Percentage of borrowers } & \multicolumn{2}{|c|}{ Percentage of non-borrowers } \\
\hline & & Before credit & After credit & 5 years back & Currently \\
\hline \multirow{6}{*}{ Monthly income (BDT) } & $0-10000$ & 50 & 11 & 62 & 40 \\
\hline & $10001-20000$ & 26 & 35 & 30 & 38 \\
\hline & $20001-30000$ & 13 & 31 & 4 & 14 \\
\hline & $30001-40000$ & 11 & 21 & 4 & 8 \\
\hline & $40001-50000$ & 0 & 0 & 0 & 0 \\
\hline & 50001 above & 0 & 2 & 0 & 0 \\
\hline \multirow{5}{*}{$\begin{array}{l}\text { Area of Homestead of the } \\
\text { Borrowers (decimal) }\end{array}$} & No land & 20 & 5 & 36 & 40 \\
\hline & $0-19$ & 53 & 45 & 44 & 56 \\
\hline & $20-39$ & 18 & 30 & 10 & 4 \\
\hline & $40-59$ & 8 & 15 & 6 & 0 \\
\hline & 60 above & 1 & 5 & 4 & 0 \\
\hline \multirow{7}{*}{$\begin{array}{l}\text { Area of Cultivable land } \\
\text { (decimal) }\end{array}$} & No land & 73 & 49 & 60 & 64 \\
\hline & $0-19$ & 5 & 10 & 18 & 22 \\
\hline & $20-39$ & 10 & 15 & 10 & 8 \\
\hline & $40-59$ & 2 & 6 & 4 & 4 \\
\hline & $60-79$ & 5 & 7 & 4 & 2 \\
\hline & $80-99$ & 4 & 8 & 2 & 0 \\
\hline & 100 above & 1 & 5 & 2 & 0 \\
\hline
\end{tabular}


Table 2 showed that before using credit, 53 percent borrowers have up to 19 decimals homestead, 18 percent have between 20-39 decimals, 8 percent have 40 to 59 decimals, and 1 percent have 60 and above decimals and 20 percent were completely landless and ' 5 years back' 36 percent non-borrowers had no land, 44 percent had up to 19 decimals, 10 percent non-borrowers had between 20 to 39 decimals, 6 percent had between 40 to 59 decimals and 4 percent non-borrowers had 60 decimals and above ; but the scenario of the poor women have been changed after joining MFI's (BRAC and ASA) due to the impact of microcredit consumption. The percentage of respondents holding an area of 20- 39 decimals homestead increased from 18 percent to 30 percent, holding an area of $40-59$ decimals increased from 8 percent to 15 percent and respondent holding land of 60 decimals and above increased from 1 percent to 5 percent found in table 2 .

Table 3. Comparison of different expenditure variables and degree of living standard before and after of consuming credits by the borrowers and current and five years back by the non-borrowers

\begin{tabular}{|c|c|c|c|c|c|}
\hline \multirow{2}{*}{ Variables } & \multirow{2}{*}{ Particulars } & \multicolumn{2}{|c|}{ Percentage of borrowers } & \multicolumn{2}{|c|}{ Percentage of non-borrowers } \\
\hline & & Before credit & After credit & 5 years back & Currently \\
\hline \multirow{4}{*}{$\begin{array}{l}\text { Monthly Total expenditure } \\
\text { (BDT) }\end{array}$} & $0-10000$ & 64 & 8 & 48 & 54 \\
\hline & $10001-20000$ & 32 & 53 & 40 & 42 \\
\hline & 20001-30000 & 3 & 32 & 6 & 2 \\
\hline & $30001 \&$ above & 1 & 5 & 6 & 2 \\
\hline \multirow{4}{*}{$\begin{array}{l}\text { Food expenditure (monthly) } \\
\text { (BDT) }\end{array}$} & $0-5000$ & 40 & 5 & 12 & 20 \\
\hline & $5001-10000$ & 38 & 36 & 54 & 60 \\
\hline & $10001-15000$ & 15 & 33 & 20 & 10 \\
\hline & $15001 \&$ above & 7 & 26 & 14 & 10 \\
\hline \multirow{5}{*}{$\begin{array}{l}\text { Education Expenditure } \\
\text { (monthly) (BDT) }\end{array}$} & $0-500$ & 43 & 13 & 48 & 40 \\
\hline & $501-1000$ & 16 & 6 & 8 & 22 \\
\hline & $1001-1500$ & 22 & 20 & 10 & 16 \\
\hline & $1501-2000$ & 6 & 4 & 4 & 4 \\
\hline & $2001 \&$ above & 13 & 57 & 30 & 18 \\
\hline \multirow{7}{*}{$\begin{array}{l}\text { Health expenditure (monthly) } \\
\text { (BDT) }\end{array}$} & $0-1000$ & 56 & 22 & 30 & 28 \\
\hline & $1001-2000$ & 26 & 25 & 24 & 36 \\
\hline & $2001-3000$ & 13 & 17 & 26 & 24 \\
\hline & $3001-4000$ & 4 & 15 & 8 & 6 \\
\hline & $4001-5000$ & 0 & 4 & 8 & 4 \\
\hline & $5001-6000$ & 0 & 5 & 2 & 2 \\
\hline & $6001 \&$ above & 1 & 12 & 2 & 0 \\
\hline \multirow{5}{*}{$\begin{array}{l}\text { Cloth Expenditure (monthly) } \\
\text { (BDT) }\end{array}$} & $0-1000$ & 87 & 55 & 78 & 42 \\
\hline & $1001-2000$ & 10 & 22 & 16 & 42 \\
\hline & $2001-3000$ & 0 & 7 & 2 & 8 \\
\hline & $3001-4000$ & 0 & 3 & 0 & 0 \\
\hline & $4001-5000$ & 0 & 5 & 0 & 4 \\
\hline \multirow[t]{6}{*}{ Condition of Dwelling House } & No house & 25 & 14 & 0 & 0 \\
\hline & clay made & 6 & 2 & 6 & 6 \\
\hline & thatch made & 19 & 2 & 4 & 4 \\
\hline & Clay and Tin & 40 & 60 & 62 & 60 \\
\hline & Semi paka & 7 & 19 & 20 & 22 \\
\hline & building & 3 & 3 & 6 & 6 \\
\hline \multirow{6}{*}{$\begin{array}{l}\text { Total Nutrition Expenditure } \\
\text { (sum of fish, meat and milk } \\
\text { (monthly) (BDT) }\end{array}$} & $0-1000$ & 50 & 19 & 36 & 40 \\
\hline & $1001-2000$ & 25 & 20 & 30 & 44 \\
\hline & $2001-3000$ & 15 & 32 & 20 & 12 \\
\hline & $3001-4000$ & 5 & 15 & 8 & 2 \\
\hline & $4001-5000$ & 3 & 10 & 4 & 2 \\
\hline & $5001 \&$ above & 2 & 4 & 2 & 0 \\
\hline \multirow[t]{2}{*}{ Choice of Hygienic Sanitation } & Yes & 56 & 93 & 52 & 70 \\
\hline & No & 44 & 7 & 48 & 30 \\
\hline \multirow[t]{2}{*}{ Choice of Pure Drinking Water } & Yes & 61 & 97 & 60 & 70 \\
\hline & No & 39 & 3 & 40 & 30 \\
\hline
\end{tabular}

Table 3 portrayed the comparison of family's monthly expenditure and other expenditure variables 'before' and 'after' of consuming credits by the borrowers and 'five years back' and 'current' expenditure by the non-borrowers. Table 3 showed that 81 percent of the borrowers had monthly education expenses up to BDT 1500 and the remaining 19 percent spent above BDT 1500 per month for education. This was the position of the respondents before credit received. It has been found that this position changed after the use of the credit by the borrowers. It is 
found that after credit the percentage of the borrowers having education expenses up to BDT 1500 per month decreased to 39 percent and the percentage of borrowers having expenses more than BDT 1500 increased to 61 percent. It was calculated from the table 1 that before credit average education expenditure was BDT 900 and after credit average education expenditure reached to BDT 1818 for the women borrowers.

In table 3 , it is found that 96 percent of the borrowers incurred monthly expenditure up to 20 thousand and the remaining 4 percent had expenditures above 20 thousand taka per month before receiving credit. The position has been changed after using credit. It was observed that the percentage of the borrowers having expenses up to BDT 20 thousand per month decreased to 61 percent and borrowers having expenses more than BDT 20 thousand increased to 37 percent. On the other hand, on ' 5 years back' 66 percent non-borrower spent for education up to BDT 1500 and remaining 34 percent of the non-borrower spent above BDT 1500 for education purpose and currently the percentage of education expenditure up to BDT 1500 per month increased to 78 percent for non borrowers.

From table 3, it is again found that 95 percent of the respondents incurred monthly health expenditure up to BDT 3000 and remaining 5 percent of the respondents (borrowers) spent above BDT 3,000 per month before receiving credit.But after receiving credits this situation have been changed. After credit the percentage of the borrower having health expenses up to BDT 3000 decreased to 64 percent and the percentage of health expenditure above BDT 3000 increased to 36 percent. On the other hand, from table 3, it is observed that ' 5 years back' monthly health expenditure of 80 percent non-borrowers was BDT up to 3000 and the remaining 20 percent of the non-borrowers spent more than BDT 3000. But currently the position has been changed nominally. Currently, the percentage of health expenditure up to BDT 3000 increased to 88 percent and the percentage of health expenditure above BDT 3,000 decreased to 12 percent. On '5 years back' average health expenditure was BDT 1800 and 'currently' it reached to BDT 1804 respectively for non-borrower respondents as reported in table 1. Therefore, it seemed that borrowers were able to increase their health expenditure by the fund generated from utilization of microcredit.Table 3 also revealed that before taking credit, 40 percent borrowers lived in clay and tin made house but after credit the percentage of the dweller of clay and tin made house increased to 60 percent. Before credit 7 percent credit receivers lived in semi paka house but after credit borrowers having semi paka house increased to 19 percent respectively.

After receiving microcredit, respondents were found aware of their health, sanitation and pure drinking water. They used credit to increase their level of living standard. It is evident that before credit 56 percent borrowers found to use hygienic sanitation and after credit use of hygienic sanitation of borrower increased to 93 percent. But in case of non-borrowers, it is observed that ' 5 years back' 52 percent non-borrower were found to use hygienic sanitation and currently 70 percent non-borrowers found to habit hygienic sanitation as showed in table 3. From table 3, it is also observed that before receiving credit, 61 percent borrowers were cast off pure drinking water and after receiving credit 97 percent borrowers were found to drink pure drinking water. But in case of non-borrowers, it is found that on ' 5 years back' 60 percent non-borrowers were found to use pure drinking water and 'currently' 70 percent non-borrowers were found to use pure drinking water respectively.

\section{Econometric Analysis: Chi-Square Test and Anova (Analysis of Variance)}

To affirm the results found from tabular analysis, econometric analysis such as Chi-Square test and ANOVA have been used to evaluate the association of variables and extent of contribution within the variables. Being consistent with the study following hypothesis for chi-square was formulated:

$\mathrm{H}_{0}-1$ : Microcredit has no impact on income.

$\mathrm{H}_{0}-2$ : Microcredit has no impact on homestead.

$\mathrm{H}_{0}-3$ : Microcredit has no impact on agricultural land.

$\mathrm{H}_{0}$ - 4: Microcredit has no impact on monthly expenditure.

$\mathrm{H}_{0}-5$ : Microcredit has no impact on food expenditure.

$\mathrm{H}_{0}-6$ : Microcredit has no impact on educational expenditure.

$\mathrm{H}_{0}-7$ : Microcredit has no impact on health expenditure.

$\mathrm{H}_{0}-8$ : Microcredit has no impact on clothing.

$\mathrm{H}_{0}-9$ : Microcredit has no impact on condition of dwelling house.

$\mathrm{H}_{0}-10$ : Microcredit has no impact on health and nutrition.

$\mathrm{H}_{0}-11$ : Microcredit has no impact on hygienic sanitation. 
$\mathrm{H}_{0}-12$ : Microcredit has no impact on access to pure drinking water.

Table 4 revealed that calculated chi-square value $\left(\chi^{2}=0.043\right)$ for income reported less than 0.05 . It implies that the impact of microcredit on the level of income is significant at the 5 percent level of significance. Thus, microcredit has a positive impact on income. It is also evident from the table 4 that in cases of acquiring agricultural land, monthly expenditure, food expenditure, health expenditure, condition of dwelling house and pure drinking water, calculated chi-square values were found as $\chi^{2}=0.004, \chi^{2}=0.000, \chi^{2}=0.006, \chi^{2}=0.005, \chi^{2}=0.007, \chi^{2}=0.0001, \chi^{2}=$ 0.001 respectively which were less than 0.05 that testimony the impact of microcredit on the agricultural land, monthly expenditure, food expenditure, health expenditure, condition of dwelling house and pure drinking water were significant at the 5 percent level of significance. However, in the case of homestead, calculated $\chi^{2}$ value $\left(\chi^{2}=\right.$ 1.679) was more than 0.05 which implied that the impact of microcredit on the level of homestead acquisition was not significant at 5 percent level of significance. It is also found from table 4 that calculated value of clothing, health and nutrition and hygienic sanitation status were $\chi^{2}=0.581, \chi^{2}=0.161$ and $\chi^{2}=0.112$ respectively which meant impact of microcredit on homestead, clothing, health \& nutrition and hygienic sanitation were not significant at the 5 percent level of significance.

Following hypothesis of ANOVA was also formulated:

$\mathrm{H}_{0}$ - 1: there is no significant difference between the borrowers and non-borrowers in the level of income.

$\mathrm{H}_{0}$ - 2: There is no significant difference between the borrowers and non-borrowers in Homestead.

$\mathrm{H}_{0}$ - 3: There is no significant difference between the borrowers and non-borrowers in the agricultural land.

$\mathrm{H}_{0}$ - 4: There is no significant difference between the borrowers and non-borrowers in Monthly expenditure.

$\mathrm{H}_{0}$ - 5: There is no significant difference between the borrowers and non-borrowers in food expenditure.

$\mathrm{H}_{0}$ - 6: There is no significant difference between the borrowers and non-borrowers in Education expenditure.

$\mathrm{H}_{0}$ - 7: There is no significant difference between the borrowers and non-borrowers in Health expenditure.

$\mathrm{H}_{0}-8$ : there is no significant difference between the borrowers and non- borrowers in clothing.

$\mathrm{H}_{0^{-}}$9: There is no significant difference between the borrowers and non-borrowers in health and nutrition.

Table 4. Results of Chi-square and ANOVA test

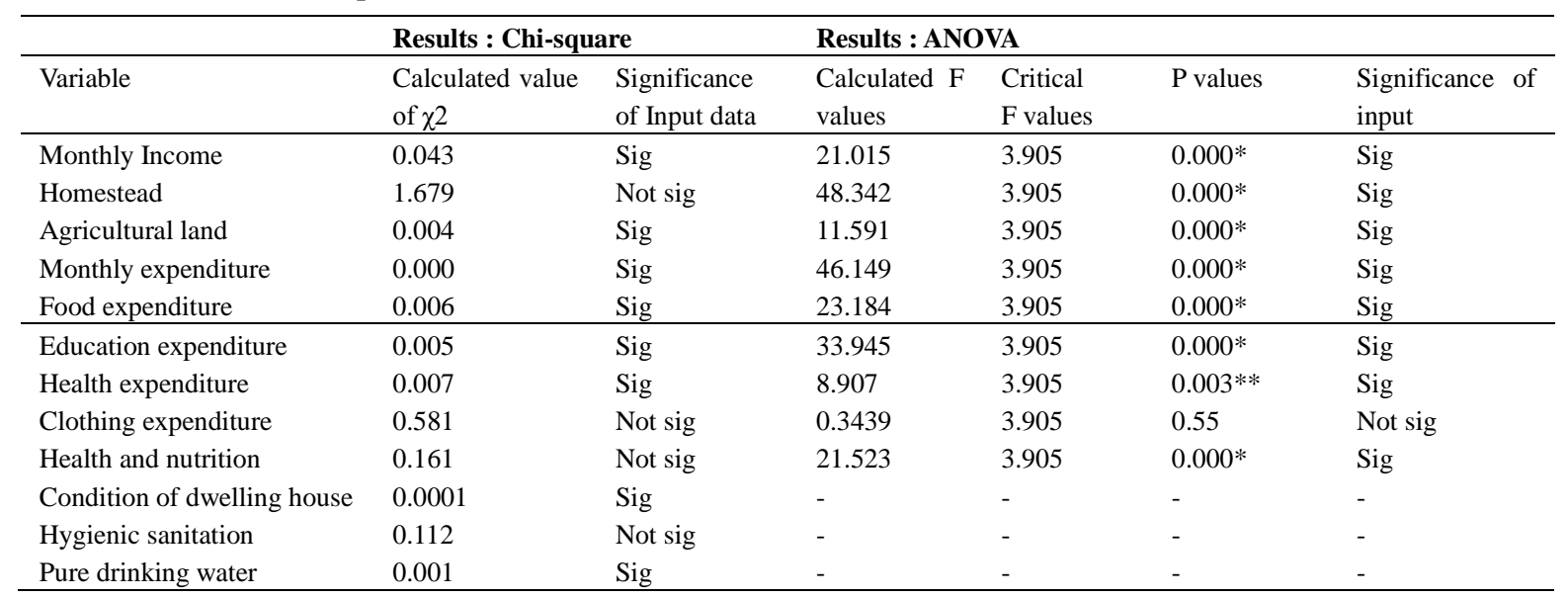

*denotes significant at less than 1 percent; ** Significant at less than 5 percent.

The statistical tool of ANOVA was used to describe the impact of microcredit on borrowers to evaluate its poverty alleviation role. To examine the relationship between microcredit and factors influenced by microcredit, nine (09) hypotheses from $\mathrm{H}_{0}-1$ to $\mathrm{H}_{0}-9$ were tested. Results are shown in table 4. Calculated value of ' $\mathrm{F}$ ' for income was 21.015, which was reported significant at 5 percent level. Therefore the hypothesis $\mathrm{H}_{0}-1$ was examined. Thus, it is established that microcredit has a positive impact on the level of income for the borrowers. From table 4, it is observed that calculated value of ' $\mathrm{F}$ ' for homestead, agricultural land, monthly expenditure, food expenditure, educational expenditure, health expenditure and health \& nutrition were found as 48.342, 11.591, 46.149, 23.184, $33.945,8.907$ and 21.523 respectively. Thus, it can be said that microcredit has a positive impact on homestead, agricultural land, monthly expenditure, food expenditure, educational expenditure, health expenditure and health $\&$ nutrition. Contrary, in case of clothing, calculated ' $F$ ' value was 0.3439 which meant the impact of microcredit 
on clothing was not significant at 5 percent level of significance. Therefore, it is found that microcredit has a negative impact on clothing. Finally, it is concluded from the above analysis that microcredit seemed to have a significant positive effect on the income, expenditure and other variables of level of living standard.

\section{Descriptive Statistics: Demographic Characteristics of the Respondents}

Among the 100 microcredit borrowers, 51 from BRAC and 49 from ASA were selected for this survey who received credit from 10 branches of BRAC and ASA respectively. For the comparison between borrowers and non-borrowers a sample of 50 non-borrowers were also selected from that area for analysis. Baseline demographic data of the borrowers and non-borrowers were collected to depict the characteristics of respondents such as age, marital status, education, factor influencing credit decision, purpose of receiving credit by the respondent that are presented below in table 5 .

Table 5. Demographic characteristics of the respondent borrowers and non-borrowers \& purpose of receiving credit by the women borrowers in the study areas

\begin{tabular}{|c|c|c|c|}
\hline Demographic Characteristics & Parameter (Range) & Percentage of Borrower & Percentage of Non-Borrower \\
\hline \multirow[t]{4}{*}{ Age Group } & $0-30$ & 35 & 32 \\
\hline & $31-40$ & 38 & 38 \\
\hline & $41-50$ & 27 & 28 \\
\hline & 51 above & 0 & 02 \\
\hline \multirow{4}{*}{ Marital Status } & Married & 93 & 90 \\
\hline & Unmarried & 01 & 02 \\
\hline & Divorced & 02 & 04 \\
\hline & widow & 04 & 04 \\
\hline \multirow[t]{4}{*}{ Level of education } & Illiterate & 5 & 20 \\
\hline & Can sign only & 32 & 27 \\
\hline & Primary & 41 & 35 \\
\hline & secondary & 22 & 18 \\
\hline \multirow[t]{5}{*}{ Influencing Borrowing Decision } & Husband's inspiration & 30 & $\mathrm{n} / \mathrm{a}$ \\
\hline & Own wishes & 20 & $\mathrm{n} / \mathrm{a}$ \\
\hline & NGO personal & 25 & $\mathrm{n} / \mathrm{a}$ \\
\hline & Neighbor & 20 & $\mathrm{n} / \mathrm{a}$ \\
\hline & Others & 05 & $\mathrm{n} / \mathrm{a}$ \\
\hline Purposes of Credit Received & & Occu & rence of Credit \\
\hline Productive activities & & & 61 \\
\hline Agriculture sector (crops, livestock) & & & 43 \\
\hline Trade and transport sector & & & 61 \\
\hline Small business & & & 59 \\
\hline Transport & & & 2 \\
\hline Social sector & & & 25 \\
\hline Health & & & 3 \\
\hline Education & & & 3 \\
\hline Housing & & & 19 \\
\hline Others & & & 5 \\
\hline
\end{tabular}

\section{Summery of the Results and Discussion}

The study has represented the real features of rural Bangladeshi women. Microcredit programme are provided to the village women where different size of loans help develop their economic condition. This study has reviewed the microcredit programme initiated by BRAC and ASA in some selected areas of Chittagong district and attempted to assess the efficiency of microcredit in reducing poverty in the study areas. According to the socio demographic profile, majority falls into the age group of 25 to 40 years. This fact suggested that the credit programme is targeted towards an actively working age group. It is found that housewives get priority in credit sanction. The literacy rate of the respondents of the study areas is very poor. Only 27 percent can sign only, 20 percent is literate and there is no graduate at all. Most of the borrowers have no idea about service charge; they only can sign security paper at the time of borrowing. Majority of them are married and when they face some financial problem their husband encourages them to take loan from the MFIs. In this study, it is found that many borrowers availed loan from more than one MFI's. In most of the cases, the study revealed a positive impact of microcredit on poverty alleviation. But a few hypotheses revealed less significant impact.

In this study, first hypothesis of chi-square analysis anticipated that microcredit programmes have a positive 
impact on the level of income. The results disclose a significant and positive relationship between income and microcredit. From tabular analysis it is also found that the borrower's average income is more than non-borrowers which indicates borrower's income position is better than non-borrowers. This result is sustained by the study of Chowdhury et al. (2005), Khandker (1998), Samer et al. (2015), Khan and Karim (2016).

Second hypothesis of chi-square reveals that there is no impact on homestead gaining or acquisition due to participation in microfinance programmes. Fourth hypothesis predicted that if there are microcredit programmes then there would be an increase in household expenditure on household items. The result reveals a positive effect of microcredit programmes on expenditure of household items. Fifth hypothesis of chi-square anticipated that microcredit programmes lead to an increase of the consumption of the food items. Results reveal positive relationship between food consumption and expenditure and microcredit programmes which is also aligned with the previous study (Kondo et al., 2008). The sixth hypothesis anticipated that microcredit programmes have a positive impact on the level of children education. The results reveal a significant and positive relationship between children education and microcredit participation. Thus, hypothesis is substantiated. These results are consistent with the findings of previous studies (Neponen, 2003;Sengsourivong, 2006) although the findings are against several studies (Coleman, 1999; Kondo, 2007).

Seventh hypothesis of chi-square shows that microcredit has a positive impact on health expenditure. This result is also consistent with previous study (Islam et al., 2014) although shows a negative impact on clothing. From this study it is found that there is a positive impact on the condition of dwelling house. That means microcredit improved house condition of the borrowers after taking loans. Tenth and eleventh hypothesis of chi-square reveals that there is no impact of microcredit on health and nutrition and hygienic sanitation. Findings of hygienic sanitation are also similar to the previous study (Khanam, 2014). But in case of pure drinking water, null hypothesis was rejected. It implies that there is a positive impact of microcredit on intake of pure drinking water by the dwellers of the investigated areas which is supported by the study of Khanam (2014). From the study, it is also found that the average medical expenditure increases than before. Women empowerment situation is improved after taking credit. This result is also supported by previous study of Banerjee et al. (2015).

From table 4, it is observed the relationship between microcredit and factors influenced by microcredit by 9 hypotheses from H0-1 to H0-9 of ANOVA, that the study tested. From the study, it can be ascertained that there is a significant difference between the borrowers and non-borrowers in respect of income, homestead, agricultural land, monthly expenditure, food expenditure, education expenditure, health expenditure, condition of dwelling house, health and nutrition, hygienic sanitation and pure drinking water. Calculated value of ' $F$ ' for income found as 21.015 which is significant at 5 percent level. Therefore, the hypothesis H0-1 is examined. It indicated that microcredit has a positive impact on the level of income for the borrowers. From table 4, it is found that calculated value of ' $\mathrm{F}$ ' for homestead, agricultural land, monthly expenditure, food expenditure, educational expenditure, health expenditure and health \& nutrition are reported as 48.342, 11.591, 46.149, 23.184, 33.945, 8.907 and 21.523 respectively. Thus, it can be summarized that microcredit has a positive impact on homestead, agricultural land, monthly expenditure, food expenditure, educational expenditure, health expenditure and health and nutrition which is revealed from study of Khandker et al. (2015). Only in the case of clothing there is no significant difference found between borrowers and non-borrowers which enlighten no significant effect of microcredit on clothing.

However, in summery it is winded up from the above analysis that microcredit seemed to have a significant positive effect on the income, expenditure and level of living standard. Findings of the study disclose that borrowers are able to improve their level of living standard by generating more income and upgrading consumption expenditure due to receipt and proper utilization of microcredit. Hence, positive impact of microcredit on poverty alleviation is further corroborated from the overall findings of the present study.

\section{Policy Recommendations}

This study has exemplified the impacts of microcredit operations of BRAC and ASA on the poverty alleviation of women borrowers. Findings stemmed from the analysis of the data of the study areas determined that the overall impacts of microcredit of BRAC and ASA are positive on the livelihood of the poor women. In some cases the impact is limited or not significant due to some hindrance on the way of the development of microcredit industry. To overcome the drawbacks of the development process and to achieve a sustainable economic growth, the following recommendations should be taken into due consideration.

\subsection{Proper Product Design \& Innovations}

Due to lack of proper designing most of the innovation of microcredit products are unreachable to the poor and are not in practiced. Therefore, the MFI's should design the products in such a simple way according to the 
diverse financial needs of the poor and keeping in mind the socio economic, political, geographical environment of the impact areas, status, needs and beliefs of its population so that the poor can easily understand and can avail the facilities.

\subsection{Research and Training}

Research and training on different contemporary issues and ideas related to the growth and development of microcredit sector, knowledge imparts, traits of diversified product portfolio, impact assessment, regional and international co-operation, integration of policy, regulation \& implementation are needed extensively.

\subsection{ExpandingProgrammes for the Ultra-Poor}

Reducing ultra-poverty is the number one target of Millennium Development Goals (MDG). Considering the severity of poverty, attempts taken by the MFIs are not enough to cope with the extreme poverty situation. National-level strategies and activities should also be taken by giving prime importance on extreme poverty reduction.

\subsection{Reaching Economically Backward Region}

Expansion of outreach of MFIs/ NGOs should effectively be reached the people of economically backward regions of the country. Being the poor are scattered throughout the remote geographical areas, the MFIs should expand their network and jurisdiction into the extreme rural parts across the country to include the most vulnerable community.

\subsection{Flexible Terms and Condition of the Credit Product}

Terms and condition of the microcredit facilities and eligibility of the borrowers should be of flexible regarding interest rate, first maximum loan amount, installment size and duration allowed between two consecutive installments (i.e. monthly) etc. Eligibility of the credit recipients should be irrespective of gender, age and marital status because poor men also need credit to generate income or to develop entrepreneurship. On the other hand, unmarried young women have more potential to build up entrepreneurship.

\subsection{Attracting More Funds}

More funds are needed to fulfill the loan requirement of the bulk number of rural poor. Fund should be raised by voluntary and compulsory savings of NGOs/MFIs, attracting funds from banks, increasing size of wholesale funds from PKSF, issuing IPO at capital markets and by convincing the international donor community.

\subsection{Strengthening Regulation and Supervision}

Cooperative Development Foundation (CDF) and Palli Karma-Sahayak Foundation (PKSF) are the regulatory bodies for microcredit sector. PKSF, in the last decade, has prepared a number of policy guidelines and standards for its Partner Organizations (POs) and for the microcredit sector to govern the microcredit practices. Microcredit Regulatory Authority Act-2006, Companies Act-1913, Trusts Act-1882, Charitable and Religious Trust Act-1920 and Cooperative Societies Ordinance-1984 have created the present regulatory framework for this industry. But till now Bangladesh is unable to prepare a National Microcredit Policy. A National Microcredit Policy framework is urgently needed to guide the sector rigorously. Supervisory approaches should also be strengthened to make MFIs more transparent and accountable.

\subsection{Roles of Government and Funding Agencies}

Governments must continue their focus on financial inclusion as a key area of policy as in the Sixth Five Year Plan (SFYP).The Government should provide sophisticated policy environment, intervene into the matter that distort the market for microcredit, focus on grant, create new legal structure for commercial MFIs, adopt appropriate regulation and supervision for microcredit and to improve the framework time to time aligned with technological advancement for secured transactions.

\subsection{Other Voluntary Services}

Besides microcredit operation, councelling, literacy programme and awareness building programme should be entertained to a larger extent to the poor women so that they can utilize the credit properly and be able to help themselves toward a decent life style.

\subsection{Responsibility on the Part of Borrower}

For sustainable microcredit development, the responsibilities of borrower community are also of importance. The borrower should repay the loan timely as per the terms and condition. This is needed for the sustainability of the loan giving institution to have a long continuance so that more and more individuals can avail the facility. 
Individual borrower or household should be free from overlapping or multiple borrowing. Borrowers should also use the credit in the productive income generating activities and should not divert the fund to unproductive purposes.

\section{Conclusive Remark}

The present study assessed the impacts of borrowing from BRAC and ASA on various dimensions of livelihood across the rural part of Chittagong district (Hathazari, Sitakunda and Mirsharai). In this study, it is found that microcredit programmes of BRAC and ASA help to improve socio economic status of the borrowing participants. Our results recommended that microcredit has a positive impact and significant contributions to household income and consumption. These results are in line with previous studies and enumerate that microcredit creates positive effects for the poor. Microcredit opens an opportunity for women borrowers to play significant role in the economic development of the country.

Bangladesh is one of the poorest countries in the world.Since independence MFIs (BRAC, ASA and the like) play a vital role to improve the poverty situation of Bangladesh. From the present study, it can be apprehended that BRAC and ASA microcredit have a positive impact on monthly income, monthly expenditure on education, health expenditure, condition of dwelling house, gaining homestead and agricultural land etc. BRAC and ASA provide their services only to the poor women. BRAC and ASA mainly involve with the practice of microcredit (loan products) only in the study area. The performance and achievement of BRAC and ASA in Chittagong is of great importance in the context of alleviating poverty of poor women. To acquire positive impacts through microcredit, recommendations provided hereby should be taken into due consideration by the MFIs and regulatory bodies of the Government, to sustain the role of microcredit portfolio in combating poverty in rural areas. More researches are needed to be carried out on the impact of microcredit on poverty alleviation through other MFIs also in Bangladesh to achieve our MDG. Though poverty is a multidimensional phenomenon, only microcredit alone cannot diminish the poverty condition, if the women borrowers are not provided with suitable microcredit products with recommended facilities along with sustainable environment for the betterment of national economic development.

\section{References}

Alnaa, S. E., \&Ahiakpor, F. (2015). Synthesis of micro-finance and technical efficiency: Implications for poverty reduction in Ghana. Research in Applied Economics, 7(1), 13-25. https://doi.org/10.5296/rae.v7i1.6599

Association for Social Advancement.(2015). Annual Report- 2015.Dhaka, Bangladesh, Association for Social Advancement (ASA).

Awan, A.G.,\&Juiya, M. J. L. (2015). Role of microcredit in poverty alleviation: evidence from Pakistan. American Journal of Trade and Policy, 2(1), 37-44. http://dx.doi.org/10.18034/ajtp.v2i1.558

Banerjee, A., Duflo, E., Glennerster, R., \&Kinnan, C. (2015). The miracle of microfinance: Evidence from a randomized evaluation. American Economic Journal: Applied Economics, 7(1), 22-53. http://dx.doi.org/10.1257/app.20130533

Bangladesh Rural Advancement Committee.(2015). Annual Report-2015. Dhaka: Bangladesh. Bangladesh Rural Advancement Committee (BRAC).

Chowdhury, M. J. A., Ghosh, D., \& Wright, R. E. (2005). The impact of micro-credit on poverty: Evidence from Bangladesh. Progress in Development Studies, 5(4), 298-309. https://doi.org/10.1191/1464993405ps116oa

Coleman, B. E. (1999). The impact of group lending in Northeast Thailand.Journal of Development Economics, 60(1), 105-141. https://doi.org/10.1016/S0304-3878(99)00038-3

Hossain, M. K. (2012). Measuring the impact of BRAC microcredit operations - A case study of a village.International Business Research, 5(4), 112-123. https://doi.org/10.5539/ibr.v5n4p112

Idris, A. J. (2015). Micro-credit as a strategy for poverty alleviation among women entrepreneurs in Nasarawa State, Nigeria.Journal of Business Studies (Quarterly), 6(3).

Islam, M. N., Hossain, T., \& Afrin, S. (2014). Impact of micro-credit to reduce poverty: A case study of Mymensingh (Vol. 31, pp. 227-240). Retrieved from https://www.researchgate.net/publication/327944192

Islam, M.S., Kabir, M.A., \&Dey, S. (2012). The role of micro credit and Micro Finance Institutions (MFIs) Extent and intensity of poverty, poverty alleviation and outreach.International Affairs and Global Strategy, 4, 29-47.

Karim, M., Tania, S., \&Farazi, M. (2013). Role of micro-credit in poverty alleviation of rural poor: Evidence from 
Laxmipur district of Bangladesh. Journal of Business and Technology (Dhaka), 7(2), 37-55. https://doi.org/10.3329/jbt.v7i2.16453

Khan, M. A.,\&Rahman, M. A. (2007).Impact of microcredit on living standards, empowerment and poverty alleviation of poor people: A case study on microcredit in the Chittagong district of Bangladesh. Umea School of Business, Master's thesis. Retrieved from http://www.diva-portal.org/smash/get/diva2:141240/fulltext01

Khan, S. R.,\&Karim, R. (2016).Impact of micro finance activities on the economic development of Bangladesh.International Journal of Finance and Banking Research, 2(1), 1-6. https://doi.org/10.11648/j.ijfbr.20160201.11

Khandker, S. R. (1998). Microfinance and poverty: Evidence using panel data from Bangladesh. World Bank Economic Review, 19(2), 263-286. https://doi.org/10.1093/wber/lhi008

Khandker, S. R., Khalily, M. A., \&Samad, H. A. (2015). Non-borrowing effects of microcredit participation: Evidence using long panel survey data in Bangladesh. Working Paper No. 41, Institute of Microfinance (InM), Dhaka.

Khanom, N. A. (2014). Rural micro credit (RMC) and poverty alleviation: The case of the PKSF in Bangladesh. International Review of Business Research Papers, 10(2), 115-136. https://doi.org/10.21102/irbrp.2014.09.102.09

Kondo, T. O. (2007). Impact of microcredit on rural households in the Philippines: A case study from the special evaluation study on the effects of microcredit operations on poor rural households and the status of women. Philippine Institute for Development Studies.

Kondo, T. O., Aniceto Jr., Dingcong, C., \&Infantado, C. (2008).Impact of microcredit on rural households in the Philippines.Discussion Paper Series no. 2008-05, Philippine Institute for Development Studies. Retrieved from http://www.eaber.org/node/22639

Mago, S. (2014). Microcredit and poverty alleviation: An empirical reflection. The Journal of Asian Finance, Economics and Business, 1(2), 5-13. https://doi.org/10.13106/jafeb.2014.vol1.no2.5

Neponen, H. (2003). ASA-GV microcredit impact report 2003. Trihcirappalli, India.The Activists for Social Alternatives, 2003.

Rahman, S., Junankar, P. N., \&Mallik, G. (2009). Factors influencing women's empowerment on microcredit borrowers: A case study in Bangladesh. Journal of the Asia Pacific Economy, 14(3), 287-303. https://doi.org/10.1080/13547860902975648

Raihan, S., Osmani, S. R., \&Khalily, M. A. B. (2015).Contribution of microcredit to the gross domestic product (GDP) of Bangladesh.InM working Paper no 44, Institute of Microfinance (InM): Dhaka.

Samer, S., Majid, I., Rizal, S., Halim, M. R. M. S., \& Rashid, N. (2015). The Impact of microcredit on poverty reduction: Empirical evidence from Malaysian perspective. Procedia-Social and Behavioral Sciences, 195, 721-728. https://doi.org/10.1016/j.sbspro.2015.06.343

Sengsourivong, K. (2005). The Impact of microcredit on household welfare: Case study of a savings group in Lao.Master Thesis, Department of Regional Cooperation Policy Studies, Kobe University, Japan.

Terano, R., Mohamed, Z., \&Jusri, J. H. H. (2015).Effectiveness of microcredit program and determinants of income among small business entrepreneurs in Malaysia.Journal of Global Entrepreneurship Research, 5(22).https://doi.org/10.1186/s40497-015-0038-3

United Nations Development Programme.(2012). International human development indicator.Country profile of human development Indicator. New York, NY 10017 USA: United Nations Development Programme (UNDP).

United Nations Development Programme. (2018). Human development indices and indicators- statistical update 2018. New York, NY 10017 USA: United Nations Development Programme (UNDP).

\section{Copyrights}

Copyright for this article is retained by the author(s), with first publication rights granted to the journal.

This is an open-access article distributed under the terms and conditions of the Creative Commons Attribution license (http://creativecommons.org/licenses/by/4.0/). 